\title{
Differential Effect of Day and Night Temperature Regimes on the Growth and Biochemical Attributes of Violet Rape (Brassica campestris ssp. chinensis L.)
}

\author{
Zhao Hong'1, Muhammad Khalid ${ }^{1}$, Muhammad Bilal', Jiaxiang Juan', \\ Danfeng Huang ${ }^{1}$, Tang Dongqin ${ }^{1 *}$ \\ ${ }^{1}$ School of Agriculture and Biology, Shanghai Jiao Tong University, Shanghai, China \\ ${ }^{2}$ State Key Laboratory of Microbial Metabolism, School of Life Sciences and Biotechnology, \\ Shanghai Jiao Tong University, Shanghai, China
}

Received: 6 October 2017

Accepted: 14 December 2017

\begin{abstract}
The present study investigated the influences of different day and night temperature regimes on the growth of violet rape (Brassica rapa var. chinensis) and pinpointed the optimal temperature combination for both yield and quality of the plant. For this purpose, the plants were grown under 6 temperature combination conditions: W1 $\left(30 / 20^{\circ} \mathrm{C}, 12-\mathrm{h}\right.$ light/12-h dark), W2 (25/15 $\mathrm{C}, 12-\mathrm{h}$ light/12-h dark), W3 (20/10 ${ }^{\circ} \mathrm{C}, 12$-h light/12-h dark), W4 (30/15 ${ }^{\circ} \mathrm{C}, 12$-h light/12-h dark), W5 (25/10 ${ }^{\circ} \mathrm{C}, 12$-h light/12-h dark), and $\mathrm{W} 6\left(30 / 10^{\circ} \mathrm{C}, 12\right.$-h light/12-h dark), and in addition we measured various morphological, yield, and biochemical traits. Results demonstrated that temperature regimes considerably affected the growth parameters of the violet rape compared with control. The W3 treatment with an average temperature of $20 / 10^{\circ} \mathrm{C}$ displayed the highest plant growth traits, including plant height $(12.74 \pm 0.24 \mathrm{~cm})$, leaf length $(8.20 \pm 0.08 \mathrm{~cm})$, leaf width $(5.44 \pm 0.16 \mathrm{~cm})$, and leaf area $\left(33.46 \pm 0.83 \mathrm{~cm}^{2}\right)$. Moreover, a highly significant correlation $(p<0.05)$ was found between temperature and soluble protein, chlorophyll, anthocyanin, nitrate nitrogen contents, and root activity; whereas the vitamin $\mathrm{C}$ and soluble sugar contents remained significantly unaffected except in the W1 treatment, under different temperature combinations between day and night. This study concluded that high temperature exerts an adverse effect on plant growth, and therefore a low day and night temperature combination is suggested in order to achieve high yield and quality for irrigated violet rape.
\end{abstract}

Keywords: temperature regimes, violet rape, morphological traits, anthocyanin, root activity

*e-mail: dqtang@sjtu.edu.cn 


\section{Introduction}

In recent decades, considerable research has focused on the influence of climate change on plant growth and final crop yield [1-2]. The efficiency of plant growth and development depends on the temperature surrounding the plant, and every species possess a defined temperature for its optimal growth. Reports have shown that over the last 100 years, the average temperature has been raised by $0.74 \pm 0.18^{\circ} \mathrm{C}[3-4]$, and heat waves are projected to become more penetrating, frequent, and last longer than currently [5]. Though extreme heat events may have the most dramatic impact on plant output, nevertheless there has been very little work carried out to document these effects. China also suffers considerably from climate change [6]. From 1960 to 2009, high-temperature stress caused by global warming has been extensively reported in the major planting areas in China [7-10].

Chinese cabbage (Brassica campestris ssp. chinensis L.), also known as violet rape (a member of the cruciferous family), is a highly consumable leafy vegetable in China and Southeast Asia [11]. As compared to other family members, it doesn't have a well-developed root system, producing sessile leave with a short stem. Due to high water and fertile soil requirements, this plant cannot tolerate water for longer periods [12-13]. Previous studies have shown that temperature for violet rape seed germination ranges $4-40^{\circ} \mathrm{C}$, but the most suited temperature lies between 20 and $25^{\circ} \mathrm{C}$, in which it grows optimally. Generally, it prefers the cold climate in spite of potential resistant capability to the high temperature of summer as compared to other family members [14]. At high temperature (above $25^{\circ} \mathrm{C}$ ), its growth becomes weaker together with poor quality and bitter taste. Violet rape is a cool-loving plant and maintains normal growth and physiology when exposed to low temperature [15].

A large number of recent studies have shown that standardization of varying temperatures and/or radiations can improve crop yield (up to $15 \%$ ), which also differs for various species [1]. However, the limitation of most previous reports lies in that only one-stage temperature influences on the growth of plants was examined, while no studies have been conducted investigating the comprehensive effects of day and night temperature set points on the growth of plants - particularly on violet rape. Therefore, the objective of our current study was to explore the influence of different temperature regimes between day and night on agronomic traits, growth, and quality of violet rape.

\section{Materials and Methods}

\author{
Experimental Site
}

The experiments were conducted in climate-regulated chambers under the phytotron at the Department of Agriculture and Biology, Shanghai Jiao Tong University, China $\left(121^{\circ} 38^{\prime} \mathrm{E}, 31^{\circ} 12^{\prime} \mathrm{N}\right)$ from December 2015 to March 2016.

\section{Agronomic Practice and Sowing}

Violet rape (Brassica campestris ssp. chinensis L.) seeds were kindly provided by Shouguang Renhe Seed Industry Co., Ltd. China. For sowing purposes, uniform and healthy seeds were chosen by hand-picking, while seeds with any visible defect, insect damage, and/ or malformation were discarded. Prior to sowing, the seeds were soaked in water and grown into a standard 200-hole tray with one seed in one hole under natural environmental conditions without any fertilizer supplementation during the seedling stage. When the seedlings developed up to 3 apparent leaves, they were transplanted into a standard 32-hole tray having a loading capacity of about 41 of substrate. Each hole of the tray was $50 \mathrm{~cm}$ (length) and $26 \mathrm{~cm}$ (width), accommodating a capacity of about $0.125-1$ substrate. The seedlings were firmly transplanted into the tray containing osmocote $(4 \mathrm{~g} / \mathrm{L})$ as basal fertilizer and water (3 liters), and soaked it for $30 \mathrm{~min}$ until substrate absorbed sufficient water. The tray was then shifted to an artificial climate chamber containing $85.0 \%$ relative humidity and fluorescent light (Philips) intensity ranging from 4,500 lx to 4,600 lx. The temperature combination conditions provided are given in Table 1 . The plants were irrigated after every 5 days and finally harvested in March 2016.

\section{Morphological Indicators}

After harvesting, fresh plant samples were transported to the laboratory and morphological parameters such as leaf area, leaf numbers, and fresh and dry weights of roots and shoots were measured. The dry weights of roots and shoots were analyzed by placing the samples in an incubator (Himac CF15R) at $105^{\circ} \mathrm{C}$ for $24 \mathrm{~h}$. Leaf area per plant was calculated by the formula:

$$
K=\frac{A}{L \times W}
$$

Table 1. Experimental design showing different temperature treatments for growth characteristics of violet rape.

\begin{tabular}{|c|c|c|c|c|c|c|c|}
\hline Treatment & W1 & W2 & W3 & W4 & W5 & W6 & CK \\
\hline Day temperature $\left({ }^{\circ} \mathrm{C}\right)$ & $30 \pm 1.0$ & $25 \pm 1.0$ & $20 \pm 1.0$ & $30 \pm 1.0$ & $25 \pm 1.0$ & $30 \pm 1.0$ & $20 \pm 1.0$ \\
\hline Night temperature $\left({ }^{\circ} \mathrm{C}\right)$ & $20 \pm 1.0$ & $15 \pm 1.0$ & $10 \pm 1.0$ & $15 \pm 1.0$ & $10 \pm 1.0$ & $10 \pm 1.0$ & $20 \pm 1.0$ \\
\hline
\end{tabular}


...where $A$ indicates the area, $K$ is the coefficient constant whose value is 0.7501 , and $L$ and $\mathrm{W}$ represent the length and width of leaf per plant, measured by means of a manual ruler.

\section{Biochemical Parameters}

\section{Vitamin C Content}

Ascorbic (AA) acid content was determined as reported previously [16]. In an Erlenmeyer flask (250-mL) containing $2.0 \mathrm{~g}$ of fresh ground leaf powder, $1.0 \mathrm{~mL}$ of $\mathrm{ZnSO}_{4}(30 \%)$ and potassium ferrocyanide $(15 \%)$ were thoroughly mixed and then $1.0 \%$ oxalic acid was added to the final volume of $100 \mathrm{~mL}$. The resulting homogenate was filtered and $2.0 \mathrm{~mL}$ of 2 , 6-dichlorophenolindophenol and $5.0 \mathrm{~mL}$ of xylene solutions were added to the $4.0 \mathrm{~mL}$ of the filtrate, vortex mixed, and optical density was recorded at $500 \mathrm{~nm}$.

\section{Anthocyanin Measurement}

For anthocyanin content measurement, $1.0 \mathrm{~mL}$ of acidic methanol [HCl, $1.0 \%(\mathrm{w} / \mathrm{v})]$ was added to $300 \mathrm{mg}$ of freshly ground plant material and samples were incubated at room temperature for $18 \mathrm{~h}$ under mild agitation. The plant material was centrifuged (1.0 min, 14,000 rpm) and $400 \mathrm{~mL}$ of clear supernatant was mixed with $600 \mathrm{~mL}$ of acidic methanol. Absorption of each sample was determined at 530 and $657 \mathrm{~nm}$ in a double-beam UV-vis spectrophotometer (HITACHI U-2900 spectrophotometer) [6].

\section{Soluble Sugar and Protein Analysis}

For soluble sugar analysis, fresh leaf sample $(0.2 \mathrm{~g})$ was taken in a test tube with $5.0 \mathrm{~mL}$ of distilled water and placed in a boiling water bath $\left(100^{\circ} \mathrm{C}\right)$ for $30 \mathrm{~min}$. The sample mixture was filtered into a volumetric flask and $5.0 \mathrm{~mL}$ Anthrone solution was added to $1.0 \mathrm{~mL}$ of filtrate followed by incubation in a water bath for $10 \mathrm{~min}$. After $10 \mathrm{~min}$, the solution was taken out, cooled to room temperature, and absorbance was measured at $620 \mathrm{~nm}$ [17]. A rapid and versatile method of Bradford using Bovine serum albumin (BSA) as standard was used for the quantification of total protein contents [18].

\section{Nitrogen Nitrate and Chlorophyll Content}

Nitrogen nitrate contents of dried plant sample were analyzed following the method of [19]. Briefly, in a beaker, $0.5 \mathrm{~g}$ root tips, $5.0 \mathrm{~mL} \mathrm{2,3,5-triphenyltetrazolium}$ chloride (TTC) solution ( $0.4 \%$ ), and $5.0 \mathrm{~mL}$ of phosphate buffer were added and the beaker was incubated at $37^{\circ} \mathrm{C}$ for $3 \mathrm{~h}$. At designated incubation time, $2.0 \mathrm{~mL}$ of $\mathrm{H}_{2} \mathrm{SO}_{4}$ $(1.0 \mathrm{M})$ was added to terminate the reaction and mixture absorbance was monitored at $485 \mathrm{~nm}$. Leaf chlorophyll content was analyzed in a manner reported previously [20].

\section{Statistical Analysis}

All the results including growth, physiological index, or biochemical parameters were reported as means along with standard deviations from 3 independent measurements. Differences between treatments were calculated by one-way ANOVA and Duncan's multiple range tests at $5.0 \%$ level of probability.

\section{Results}

\section{Morphological Characteristics of Violet Rape at Day and Night Temperature Fluctuations}

The morphological attributes during violet rape (Brassica campestris ssp. chinensis L.) development process such as leaf number, plant height, leaf length, leaf width, and leaf area were determined at different day and night temperature set points, and responses thus obtained are summarized in Table 2. The appearance of violet rape plants and their leaves cultivated under different growth conditions in temperature-controlled chambers are shown in Fig. 1. Results revealed that no significant difference $(p>0.05)$ was observed at varying temperature regimes

Table 2. Influence of differential day and night temperature set points on the morphological indexes of violet rape.

\begin{tabular}{|c|c|c|c|c|c|}
\hline Treatment & Leaf number & Plant height $(\mathrm{cm})$ & Leaf length $(\mathrm{cm})$ & Leaf width $(\mathrm{cm})$ & Leaf area $\left(\mathrm{cm}{ }^{2}\right)$ \\
\hline W1 & $\mathbf{1 2 . 6 0} \pm \mathbf{0 . 7 5 a}$ & $8.74 \pm 0.58 \mathrm{c}$ & $5.28 \pm 0.47 \mathrm{de}$ & $4.08 \pm 0.29 \mathrm{~d}$ & $16.16 \pm 2.82 \mathrm{c}$ \\
\hline W2 & $10.60 \pm 0.40 \mathrm{ab}$ & $9.14 \pm 0.21 \mathrm{c}$ & $6.00 \pm 0.16 \mathrm{~cd}$ & $5.06 \pm 0.16 \mathrm{ab}$ & $22.77 \pm 0.87 \mathrm{~b}$ \\
\hline W3 & $12.40 \pm 0.60 \mathrm{a}$ & $\mathbf{1 2 . 7 4} \pm \mathbf{0 . 2 4 a}$ & $\mathbf{8 . 2 0} \pm \mathbf{0 . 0 8 a}$ & $\mathbf{5 . 4 4} \pm \mathbf{0 . 1 6 a}$ & $\mathbf{3 3 . 4 6} \pm \mathbf{0 . 8 3 a}$ \\
\hline W4 & $11.75 \pm 0.43 \mathrm{a}$ & $10.72 \pm 0.45 \mathrm{~b}$ & $6.37 \pm 0.20 \mathrm{bc}$ & $22.71 \pm 4.69 \mathrm{~b}$ \\
\hline W5 & $12.20 \pm 0.66 \mathrm{a}$ & $11.26 \pm 0.32 \mathrm{ab}$ & $7.18 \pm 0.31 \mathrm{~b}$ & $5.38 \pm 0.18 \mathrm{a}$ & $28.97 \pm 2.11 \mathrm{a}$ \\
\hline W6 & $9.60 \pm 0.40 \mathrm{~b}$ & $6.70 \pm 0.58 \mathrm{~d}$ & $4.26 \pm 0.29 \mathrm{f}$ & $2.82 \pm 0.22 \mathrm{e}$ & $9.01 \pm 1.18 \mathrm{~d}$ \\
\hline CK & $11.60 \pm 0.81 \mathrm{a}$ & $7.38 \pm 0.46 \mathrm{~d}$ & $4.94 \pm 0.39 \mathrm{ef}$ & $4.30 \pm 0.21 \mathrm{~cd}$ & $15.93 \pm 2.03 \mathrm{c}$ \\
\hline
\end{tabular}

Bold values indicate the highest response of any respective parameter; mean values indicated by dissimilar lowercase letters are significantly different from each other $(\mathrm{p}<0.05)$; values are means \pm SDs $(n=15)$ 

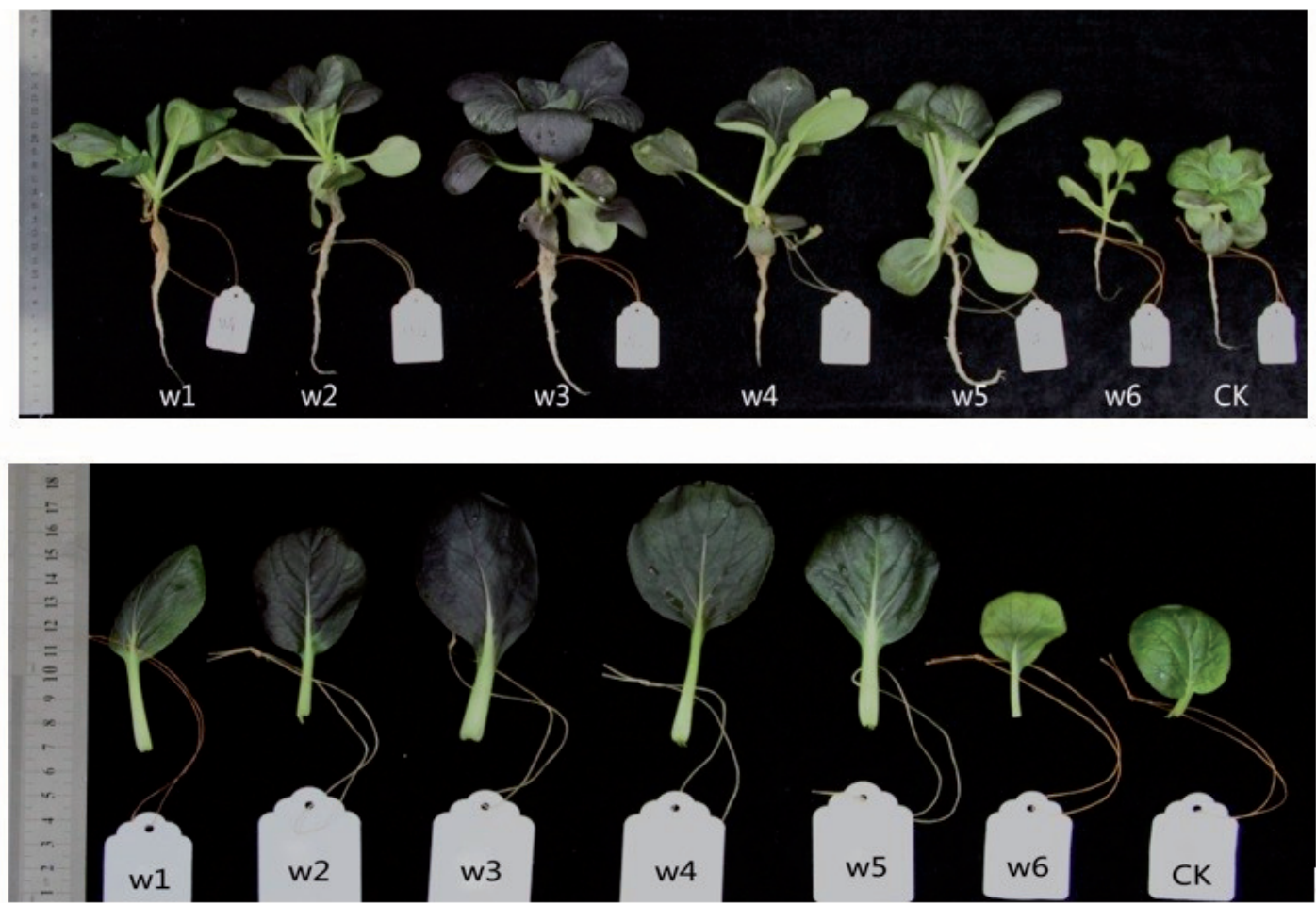

Fig. 1. The appearance of violet rape plant cultivated under different growth conditions in temperature-controlled chambers: Control (CK) $20^{\circ} \mathrm{C}, 12$-h light $/ 12$-h dark cycle; $\mathrm{W} 130 / 20^{\circ} \mathrm{C}, 12$-h light/12-h dark cycle; W2 25/15 ${ }^{\circ} \mathrm{C}, 12$-h light/12-h dark cycle; W3 20/10 ${ }^{\circ} \mathrm{C}$, 12-h light/12-h dark cycle; W4 30/15 ${ }^{\circ} \mathrm{C}, 12$-h light/12-h dark cycle; W5 25/10 ${ }^{\circ} \mathrm{C}, 12$-h light/12-h dark cycle; and W6 30/10 ${ }^{\circ} \mathrm{C}, 12-\mathrm{h}$ light/12-h dark cycle (upper panel, overall views of plants at different temperature treatments; lower panel, view of plant leaves at different treatments).

for leaf numbers, and all the temperature set points to give rise to more than 10 leaves except W6 treatment $\left(30 / 10^{\circ} \mathrm{C}, 12\right.$-h light/12-h dark). Noticeably, the highest leaf numbers (up to 12.60$)$ were recorded in $\mathrm{W} 1\left(30 / 20^{\circ} \mathrm{C}\right.$, 12-h light/12-h dark) followed by W3 $\left(20 / 10^{\circ} \mathrm{C}, 12-\mathrm{h}\right.$ light/12-h dark cycle), and $\mathrm{W} 5\left(25 / 10^{\circ} \mathrm{C}, 12\right.$-h light/12-h dark). Nevertheless, these treatments were statistically not significant with respect to control $\left(\mathrm{CK}, 20^{\circ} \mathrm{C}, 12-\mathrm{h}\right.$ light/12-h dark). The plant's height showed a fluctuating trend at different temperature combinations. The highest plant height was noted in W3 $(12.74 \mathrm{~cm})$, followed by W5 $(11.26 \mathrm{~cm})$, whereas it was smallest in the W6 $(6.70 \mathrm{~cm})$ combination. Moreover, a significantly positive correlation $(p<0.05)$ was found at various temperature treatments for leaf length, leaf width, and leaf area and, as a consequence, the W3 temperature regime exhibited superior results for all these agronomic traits.

As shown in Table 3, among all the treatments, W3 portrays a better performance for plant fresh weight, shoot fresh and dry, as well as root fresh and dry weights. The recorded improvements were $68.09 \%, 66.10 \%$, $80.71 \%, 61.22 \%$, and $85.71 \%$ for plant fresh weight, shoot

Table 3: Influence of differential day and night temperature set points on the growth parameters of violet rape.

\begin{tabular}{|c|c|c|c|c|c|c|}
\hline Treatment & $\begin{array}{c}\text { Plant fresh } \\
\text { weight }(\mathrm{g})\end{array}$ & $\begin{array}{c}\text { Shoot fresh } \\
\text { weight }(\mathrm{g})\end{array}$ & $\begin{array}{c}\text { Root fresh } \\
\text { weight }(\mathrm{g})\end{array}$ & $\begin{array}{c}\text { Shoot dry weight } \\
(\mathrm{g})\end{array}$ & $\begin{array}{c}\text { Root dry weight } \\
(\mathrm{g})\end{array}$ & $\begin{array}{c}\text { Root-shoot } \\
\text { ratio }\end{array}$ \\
\hline W1 & $5.15 \pm 0.73 \mathrm{c}$ & $4.37 \pm 0.62 \mathrm{c}$ & $0.79 \pm 0.11 \mathrm{c}$ & $0.36 \pm 0.05 \mathrm{~b}$ & $0.05 \pm 0.01 \mathrm{a}$ & $0.18 \pm 0.01 \mathrm{ab}$ \\
\hline W2 & $5.80 \pm 0.40 \mathrm{c}$ & $4.78 \pm 0.38 \mathrm{c}$ & $1.01 \pm 0.1 \mathrm{ab}$ & $0.32 \pm 0.03 \mathrm{~b}$ & $0.05 \pm 0.01 \mathrm{a}$ & $\mathbf{0 . 2 1} \pm \mathbf{0 . 0 3 a}$ \\
\hline W3 & $\mathbf{1 0 . 2 5} \pm \mathbf{0 . 6 9 a}$ & $\mathbf{8 . 8 5} \pm \mathbf{0 . 5 5 a}$ & $\mathbf{1 . 4 0} \pm \mathbf{0 . 3 0 a}$ & $\mathbf{0 . 4 9} \pm \mathbf{0 . 0 4 a}$ & $\mathbf{0 . 0 7} \pm \mathbf{0 . 0 2 a}$ & $0.16 \pm 0.03 \mathrm{ab}$ \\
\hline W4 & $5.63 \pm 0.51 \mathrm{c}$ & $5.08 \pm 0.43 \mathrm{c}$ & $0.56 \pm 0.11 \mathrm{bc}$ & $0.33 \pm 0.03 \mathrm{~b}$ & $0.03 \pm 0.00 \mathrm{ab}$ & $0.11 \pm 0.02 \mathrm{~b}$ \\
\hline W5 & $8.19 \pm 0.45 \mathrm{~b}$ & $7.17 \pm 0.48 \mathrm{~b}$ & $1.01 \pm 0.11 \mathrm{ab}$ & $0.42 \pm 0.02 \mathrm{ab}$ & $0.05 \pm 0.01 \mathrm{a}$ & $0.14 \pm 0.02 \mathrm{ab}$ \\
\hline W6 & $1.58 \pm 0.14 \mathrm{e}$ & $1.41 \pm 0.15 \mathrm{e}$ & $0.17 \pm 0.05 \mathrm{c}$ & $0.09 \pm 0.01 \mathrm{~d}$ & $0.01 \pm 0.00 \mathrm{~b}$ & $0.13 \pm 0.05 \mathrm{ab}$ \\
\hline CK & $3.27 \pm 0.29 \mathrm{~d}$ & $3.00 \pm 0.26 \mathrm{~d}$ & $0.27 \pm 0.09 \mathrm{c}$ & $0.19 \pm 0.00 \mathrm{c}$ & $0.01 \pm 0.00 \mathrm{~b}$ & $0.09 \pm 0.03 \mathrm{~b}$ \\
\hline
\end{tabular}

Bold values indicate the highest response of any respective parameter; mean values indicated by dissimilar lowercase letters are significantly different from each other $(\mathrm{p}<0.05)$; values are means \pm SDs $(n=15)$ 

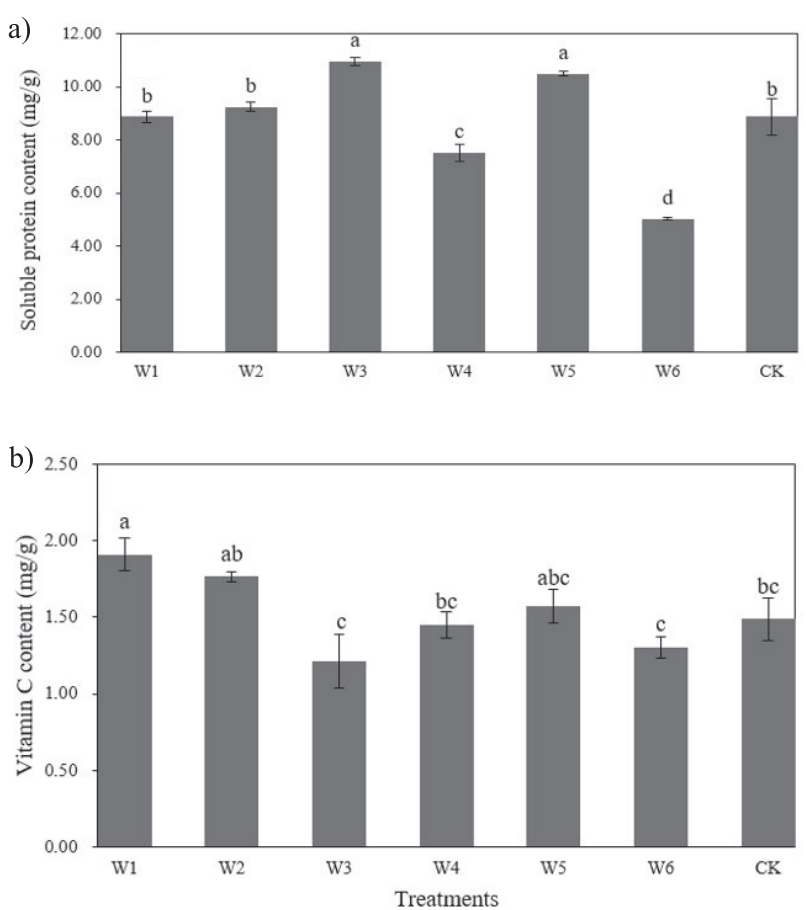

Fig. 2. a) Soluble protein content of violet rape cultivated under different day and night temperature set points and b) vitamin $\mathrm{C}$ content of violet rape cultivated under different day and night temperature combinations; mean values indicated by dissimilar lowercase letters represent significant differences from each other $(\mathrm{p}<0.05)$.

fresh weight, root fresh weight, shoot dry weight and root dry weight, respectively, as compared to control (CK). Minimal plant fresh weight was observed in W6 treatment (only $1.58 \mathrm{~g}$ ), and even less than half of the CK. On the other hand, the root-shoot ratio was found to be $57.14 \%$ higher in W2 contrasted with control.

\section{Biochemical Parameters of Violet Rape at Day and Night Temperature Regimes}

The effects of different day and night temperature amalgamations were also investigated on different biochemical parameters of violet rape such as

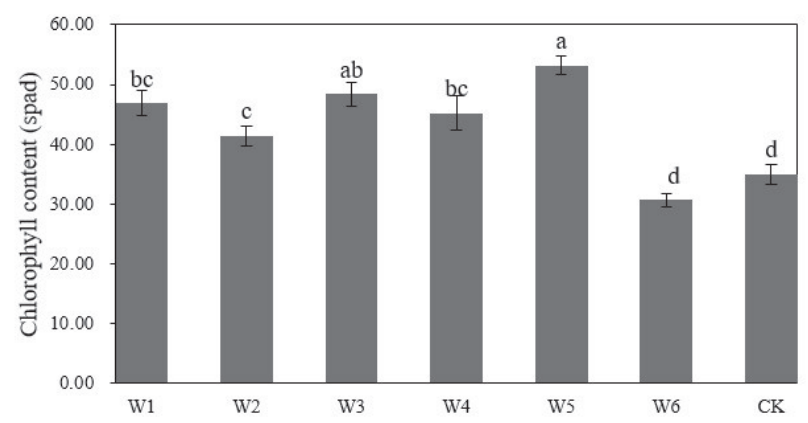

Fig. 3. Chlorophyll content of violet rape cultivated under different day and night temperature set points; mean values indicated by dissimilar lowercase letters are significantly different from each other $(\mathrm{p}<0.05)$.
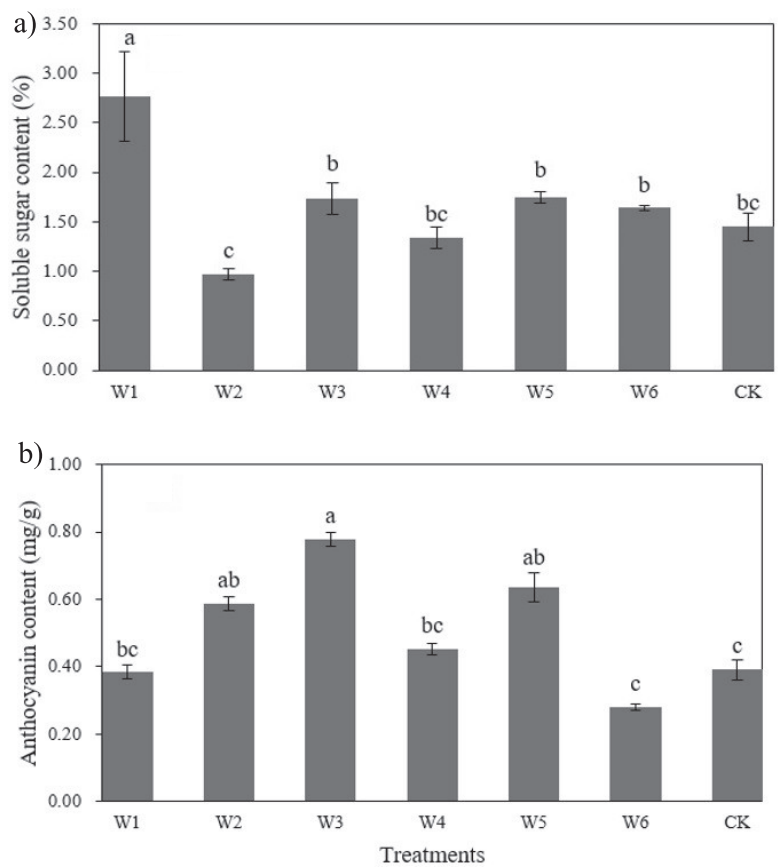

Fig. 4. a) Soluble sugar content of violet rape cultivated under different day and night temperature combinations and b) the anthocyanin content of violet rape cultivated under different day and night temperature combinations; mean values indicated by dissimilar lowercase letters are significantly different from each other $(\mathrm{p}<0.05)$.

soluble protein, vitamin C, chlorophyll, soluble sugar, anthocyanin, nitrate nitrogen contents, and root activity. Notably, soluble protein contents were found to be significantly different $(p<0.05)$ at all the temperature treatments (Fig. 2a). In contrast to CK, the day and night temperature combination of W3 and W5 led to $23.96 \%$ and $18.38 \%$ higher protein contents, respectively. Whereas W6 and W4 treatments decreased the protein content by $43.40 \%$ and $15.45 \%$, respectively, as compared to CK. As shown in Fig. 2b, the vitamin $\mathrm{C}$ content remained significantly unchanged under different temperature combinations between day and night. Maximum vitamin C recorded in W1 $(1.91 \mathrm{mg} / \mathrm{g})$ was $28.19 \%$ greater than CK, while other groups did not show any noticeable change in vitamin $\mathrm{C}$ compared to CK. In all six temperature regimes, chlorophyll contents were found to be highest in W5 (53.18 spads), followed by W3 (48.38 spads; Fig. 3). The percentage enhancements were $34.11 \%$ and $27.58 \%$, respectively, compared to CK. The chlorophyll in W6 was $12.56 \%$ lower than CK, but this decline was not significant. Similarly, no significant difference between different treatments was observed for soluble sugar content except the W1 treatment. The soluble sugar content in the W1 and W2 treatment was $91.03 \%$ higher and $33.10 \%$ lower than that of control (Fig. 4a). Violet rape temperature treatments exhibited a significant influence on the content of anthocyanin (Fig. 4b). In W3, best anthocyanin content attained ( 0.78 $\mathrm{mg} / \mathrm{g}$ ) was $50 \%$ superior to control, while in case of W1 

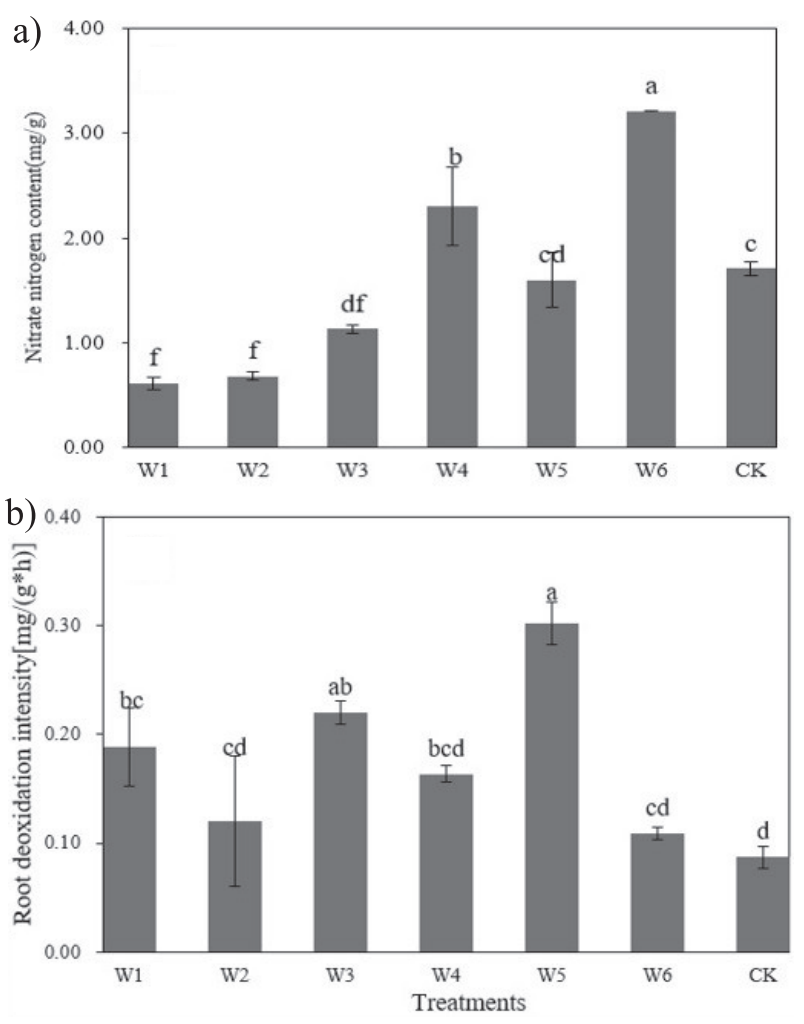

Fig. 5. a) The nitrate nitrogen content of violet rape cultivated under different day and night temperature set points and b) root de-oxidation intensity of violet rape cultivated under different day and night temperature combinations; mean values indicated by dissimilar lowercase letters are significantly different from each other $(\mathrm{p}<0.05)$.

and W6 treatments, anthocyanin content was $2.56 \%$ and $39.28 \%$ less than CK. Fig. 5a) portrays nitrate-nitrogen contents on different day and night temperatures to show a positive correlation. The order for nitrate-nitrogen contents was $\mathrm{W} 1<\mathrm{W} 2<\mathrm{W} 3<\mathrm{W} 5<\mathrm{W} 4<\mathrm{W} 6$. The nitrate contents in W1, W2, and W3 were $64.33 \%, 60.23 \%$, and $33.92 \%$ lower than that of CK, while it was the highest in W6, about $87.72 \%$ higher than CK. The obvious differences in root activity intensity were observed at varying temperature combinations (Fig. 5b). W5 possessed the strongest root activity $-0.30 \mathrm{mg} /(\mathrm{g} * \mathrm{~h})$, which was $70 \%$ greater in caparison to CK. The root activities in $\mathrm{W} 5, \mathrm{~W} 3$, and $\mathrm{W} 1$ were 3.3, 2.4, and 2.1 times higher, respectively, with respect to control.

\section{Discussion}

Temperature is the main ecological factor that considerably influences growth development of agricultural plants [21-22]. Sometimes the developmental process of violet rape is not essentially the same in different planting dates in spite of the same cumulative climate data of those sowing dates. Therefore, the standardized amalgamation of day and night temperature set points is of great value for efficient growth of any plant. The knowledge of optimized day and night temperature regimes would undoubtedly contribute to a suitable sowing date schedule so as to assure each stage in its optimal temperature range. Low-temperature level during plant growth stage drastically decelerates leaf enlargement, leaf numbers, and total uptake at maturity [23-24]. On the other hand, high-temperature stress during or after flowering is quite unfavorable for plant growth, and several authors have reported a marked reduction in plant biomass, which eventually resulted in poor quality and production of food crops [25-26]. In common bean (Phaseolus vulgaris), morpho-physiological attributes such as phenology, plant-water relations, shoot and root growth, and elongations are seriously hindered due to elevated heat stress [27]. In some other plant species, high-temperature causes noteworthy elongated stems and leaves, while total biomass was reduced [28-29]. The green leaf area and productive tillers were drastically diminished under high temperature $\left(30 / 25^{\circ} \mathrm{C}\right.$, day/night) [30]. Various plants show programmed cell death in specific cells or tissues following exposure to extreme heat stress due to aggregation and/or denaturation of proteins, while a moderately higher temperature for longer duration causes shedding of leaves or even death of the whole plant [31-32].

Deng and co-workers (2015) investigated the average maximum and minimum daily temperatures in the rice phenological stages, ranging from 22.4 to $29.1^{\circ} \mathrm{C}, 26.2$ to $31.8^{\circ} \mathrm{C}$, and 21.6 to $30.6^{\circ} \mathrm{C}$ in vegetative, reproductive, and grain-filling stages, respectively [1]. The optimum temperature in vegetative and grain-filling stages was recorded to be $28^{\circ} \mathrm{C}$ and $22^{\circ} \mathrm{C}$, respectively. They recommended a range of 26 to $28^{\circ} \mathrm{C}$ to be the optimal average daily temperature in vegetative stage to get the best crop yield. In another study, Sanchez et al. (2014) evaluated the one-stage temperature influences on the growth of plants and found $28.4^{\circ} \mathrm{C}$ to be optimal for tillering [33-34]. It has been reported that a combined temperature optimization strategy is useful in practical applications, while the one-stage study is more suitable for basic/elementary research [1].

The cooperating influences of environmental temperatures on growth and physiological attributes of Pisum sativum were investigated by Martel and Qaderi (2016), and found that higher temperatures and supplemental UV-B radiation significantly reduced the plant growth rate by decreasing stem height, diameter, and leaf area [35]. The findings were in agreement with earlier reports on crops, including canola [36] and peas [37] as well as some higher plants [38].

According to the best of our knowledge, no other such climatic study has been reported with violet rape evaluating biochemical parameters in response to different temperature combinations. For turnip roots (B. rapa L.), Shattuck and coworkers, (1991b) observed that low growth temperature for short periods does not affect ascorbic acid content [39]. The vitamin C content seems to be the highest at low growth temperatures in broccoli [40]. As compared to $7-12^{\circ} \mathrm{C}$, the elevated 
temperatures $\left(15-20^{\circ} \mathrm{C}\right)$ led to $38 \%$ reduction in the content of ascorbic acid in greenhouse-grown broccoli. In a controlled climate study $\left(21 / 15^{\circ} \mathrm{C}\right.$ and $15 / 9^{\circ} \mathrm{C}$ (day/night)), Steindal and coworkers (2013) recorded a $16 \%$ reduction in vitamin $\mathrm{C}$ content at the higher temperatures for $12 \mathrm{~h}$ and $24 \mathrm{~h}$ day length. Conversely, Molmann et al. (2015) found no significant differences in vitamin $\mathrm{C}$ content between broccoli grown at $12^{\circ} \mathrm{C}$ and $18^{\circ} \mathrm{C}$ [41]. The utmost levels of total sugar content were found for treatments $21 / 15 / 9^{\circ} \mathrm{C}$ and $15 / 9 / 6^{\circ} \mathrm{C}$, both with a significant difference to the lower level at $21^{\circ} \mathrm{C}$ [42]. Shattuck et al. (1991a) reported that a low growth temperature $\left(0-12^{\circ} \mathrm{C}\right)$ for 11 days before harvesting considerably increased the total sugar content [39-43]. Comparable results have also been reported by Davik (1992) and Shattuck et al. (1991a).

Our study in controlled climate chambers clearly showed the biochemical responses to various designated treatments and contributed an insight of possible temperature effects on morphological and biochemical properties in violet rape. As for consumer's preference, the findings revealed that high cultivation temperatures do not benefit eating quality. Nevertheless, the results should be strengthened by field studies, where several other environmental factors including light conditions, day-length, light intensity, and spectral composition might influence both morphological and biochemical properties.

\section{Conclusions}

It is of great concern to select an appropriate day and night temperature regime so as to accommodate optimal local climatic conditions according to the requirements of a plant to achieve the utmost growth and yield. The results revealed that $\mathrm{W} 3$ combination with an average temperature of $20 / 10^{\circ} \mathrm{C}$ and 12 -h light/12-h dark led to highest plant growth and morphological attributes. Though the biochemical characteristics of violet rape showed great variations in different temperature set points, lower temperatures were found to be better. These findings would definitely provide guidance to farmers for the cultivation of other crops (such as wheat, maize, and rapeseed, etc.) aimed at improving yield and quality.

\section{Acknowledgements}

This work was supported by the National High Technology Research and Development Program (863) of China under grant No. 2013AA103006 from the Ministry of Science and Technology of China.

\section{References}

1. DENG N., LING X., SUN Y., ZHANG C., FAHAD S., PENG S., CUI K., NIE L., HUANG J. Influence of temperature and solar radiation on grain yield and quality in irrigated rice system. European Journal of Agronomy. 64, 37, 2015.

2. PENG S., HUANG J., SHEEHY J.E., LAZA RC., VISPERAS R.M., ZHONG X., CENTENO G.S., KHUSH G.S., CASSMAN K.G. Rice yields decline with higher night temperature from global warming. Proceedings of the National Academy of Sciences of the United States of America. 101 (27), 9971, 2004.

3. SOLOMON S., QIN D., MANNING M., CHEN Z., MARQUIS M., AVERYT K., TIGNOR M., MILLER H. Contribution of working group I to the fourth assessment report of the intergovernmental panel on climate change, 2007. Cambridge University Press, Cambridge. 2007.

4. TEBALDI C., HAYHOE K., ARBLASTER J.M., MEEHL G.A. Going to the extremes. Climatic Change. 79 (3-4), 185, 2006.

5. MEEHL GA., WASHINGTON WM., ARBLASTER JM., HU A., TENG H., KAY JE., GETTELMAN A., LAWRENCE DM., SANDERSON BM., STRAND WG. Climate change projections in CESM1 (CAM5) compared to CCSM4. Journal of Climate. 26 (17), 6287, 2013.

6. KHALID M., BILAL M., HASSANI D., IQBAL H.M., WANG H., HUANG D. Mitigation of salt stress in white clover (Trifolium repens) by Azospirillum brasilense and its inoculation effect. Botanical Studies. 58 (1), 5, 2017.

7. HUANG R.J., ZHANG Y., BOZZETTI C., HO K.F., CAO J.J., HAN Y., DAELLENBACH K.R., SLOWIK J.G., PLATT S.M., CANONACO F. High secondary aerosol contribution to particulate pollution during haze events in China. Nature. 514 (7521), 218, 2014.

8. LIN T., QIN Y., ZHENG B., LI Y., CHEN Y., GUO Z. Source apportionment of polycyclic aromatic hydrocarbons in the Dahuofang Reservoir, Northeast China. Environmental Monitoring and Assessment. 185 (1), 945, 2013.

9. TAO M., CHEN L., XIONG X., ZHANG M., MA P., TAO J., WANG Z. Formation process of the widespread extreme haze pollution over northern China in January 2013: Implications for regional air quality and climate. Atmospheric Environment. 98, 417, 2014.

10. ZHANG R., JING J., TAO J., HSU S-C., WANG G., CAO J., LEE C.S.L., ZHU L., CHEN Z., ZHAO Y. Chemical characterization and source apportionment of PM2.5 in Beijing: seasonal perspective. Atmospheric Chemistry and Physics. 13 (14), 70532013.

11. KHALID M., HASSANI D., BILAL M., LIAO J., HUANG D. Elevation of secondary metabolites synthesis in Brassica campestris ssp. chinensis L. via exogenous inoculation of Piriformospora indica with appropriate fertilizer. PLOS ONE. 12, 0177185, 2017.

12. AJISAKA H., KUGINUKI Y., YUI S., ENOMOTO S., HIRAI M. Identification and mapping of a quantitative trait locus controlling extreme late bolting in Chinese cabbage (Brassica rapa L. ssp. pekinensis syn. campestris L.) using bulked segregant analysis. Euphytica. 118 (1), 75. 2001.

13. TAKUNO S., KAWAHARA T., OHNISHI O. Phylogenetic relationships among cultivated types of Brassica rapa L. em. Metzg. as revealed by AFLP analysis. Genetic Resources and Crop Evolution. 54 (2), 279, 2007.

14. NXAWE S., NDAKIDEMI P., LAUBSCHER C. Possible effects of regulating hydroponic water temperature on plant growth, accumulation of nutrients and other metabolites. African Journal of Biotechnology. 9 (54), 9128, 2010.

15. MAHMUD T.M.M., ATHERTON J.G., WRIGHT C.J., RAMLAN M.F., AHMAD S.H. Pak Choi (Brassica rapa ssp Chinensis L) quality response to pre-harvest salinity 
and temperature. Journal of the Science of Food and Agriculture. 79 (12), 1698, 1999.

16. FRANCISCO M., VELASCO P., MORENO D.A., GARCÍA-VIGUERA C., CARTEA M.E. Cooking methods of Brassica rapa affect the preservation of glucosinolates, phenolics and vitamin C. Food Research International. 43 (5), 1455, 2010.

17. BUYSSE J., MERCKX R. An improved colorimetric method to quantify sugar content of plant tissue. Journal of Experimental Botany. 44 (10), 1627, 1993.

18. SEDMAK J.J., GROSSBERG S.E. A rapid, sensitive, and versatile assay for protein using Coomassie brilliant blue G250. Analytical Biochemistry. 79 (1-2), 544, 1977.

19. POWELL W., CATRANIS C., MAYNARD C. Design of self-processing antimicrobial peptides for plant protection. Lett Appl Microbiol. 31 (2), 163, 2000.

20. PORRA R., THOMPSON W., KRIEDEMANN P. Determination of accurate extinction coefficients and simultaneous equations for assaying chlorophylls a and b extracted with four different solvents: verification of the concentration of chlorophyll standards by atomic absorption spectroscopy. Biochimica et Biophysica Acta (BBA)-Bioenergetics. 975 (3), 384, 1989.

21. CHAPMAN V.J. Coastal vegetation: Elsevier. 2016.

22. HU J., WU W., CAO Z., WEN J., SHU Q., FU S. Morphological, physiological and biochemical responses of Camellia oleifera to low-temperature stress. Pakistan Journal of Botany. 48 (3), 899, 2016.

23. SHIMONO H., FUJIMURA S., NISHIMURA T., HASEGAWA T. Nitrogen uptake by rice (Oryza sativa L.) exposed to low water temperatures at different growth stages. Journal of Agronomy and Crop Science. 198 (2), 145, 2012.

24. SHIMONO H., OKADA M., KANDA E., ARAKAWA I. Low temperature-induced sterility in rice: Evidence for the effects of temperature before panicle initiation. Field Crops Research. 101 (2), 221, 2007.

25. LIU Q., WU X., MA J., LI T., ZHOU X., GUO T. Effects of high air temperature on rice grain quality and yield under field condition. Agronomy Journal. 105 (2), 446, 2013.

26. SHI W., MUTHURAJAN R., RAHMAN H., SELVAM J., PENG S., ZOU Y., JAGADISH K.S. Source-sink dynamics and proteomic reprogramming under elevated night temperature and their impact on rice yield and grain quality. New Phytologist. 197 (3), 825, 2013.

27. KOINI M.A., ALVEY L., ALLEN T., TILLEY C.A., HARBERD N.P., WHITELAM G.C., FRANKLIN K.A. High temperature-mediated adaptations in plant architecture require the bHLH transcription factor PIF4. Current Biology. 19 (5), 408, 2009.

28. PASSARELLA V.S., SAVIN R., SLAFER G.A. Grain weight and malting quality in barley as affected by brief periods of increased spike temperature under field conditions. Crop and Pasture Science. 53 (11), 1219, 2002.

29. PATEL D., FRANKLIN K.A. Temperature-regulation of plant architecture. Plant Signaling \& Behavior. 4 (7), 577, 2009.

30. DJANAGUIRAMAN M., PRASAD P., SEPPANEN M. Selenium protects sorghum leaves from oxidative damage under high temperature stress by enhancing antioxidant defense system. Plant Physiology and Biochemistry. 48 (12), 999, 2010

31. HASANUZZAMAN M., NAHAR K., ALAM M.M., ROYCHOWDHURY R., FUJITA M. Physiological, biochemical, and molecular mechanisms of heat stress tolerance in plants. International Journal of Molecular Sciences. 14 (5), 9643, 2013.

32. RODRÍGUEZ M., CANALES E., BORRÁS-HIDALGO O. Molecular aspects of abiotic stress in plants. Biotecnología Aplicada. 22 (1), 1, 2005.

33. RIVERO R.M., MESTRE T.C., MITTLER R., RUBIO F., GARCIA-SANCHEZ F., MARTINEZ V. The combined effect of salinity and heat reveals a specific physiological, biochemical and molecular response in tomato plants. Plant, Cell \& Environment. 37 (5), 1059, 2014.

34. SÁNCHEZ B., RASMUSSEN A., PORTER J.R. Temperatures and the growth and development of maize and rice: a review. Global Change Biology. 20 (2), 408 , 2014.

35. MARTEL A.B., QADERI M.M. Does salicylic acid mitigate the adverse effects of temperature and ultraviolet-B radiation on pea (Pisum sativum) plants? Environmental and Experimental Botany. 122, 39, 2016.

36. SANGTARASH M., QADERI M., CHINNAPPA C., REID D. Differential sensitivity of canola (Brassica napus) seedlings to ultraviolet-B radiation, water stress and abscisic acid. Environmental and Experimental Botany. 66 (2), 212, 2009.

37. CHOUDHARY K.K., AGRAWAL S. Ultraviolet-B induced changes in morphological, physiological and biochemical parameters of two cultivars of pea (Pisum sativum L.). Ecotoxicology and Environmental Safety. 100, 178, 2014.

38. BALLARÉ C.L., CALDWELL M.M., FLINT S.D., ROBINSON S.A., BORNMAN J.F. Effects of solar ultraviolet radiation on terrestrial ecosystems. Patterns, mechanisms, and interactions with climate change. Photochemical \& Photobiological Sciences. 10 (2), 226, 2011.

39. SHATTUCK V., KAKUDA Y., SHELP B., KAKUDA N. Chemical composition of turnip roots stored or intermittently grown at low temperature. Journal of the American Society for Horticultural Science. 116 (5), 818, 1991.

40. SCHONHOF I., KLÄRING H.P., KRUMBEIN A., CLAUßEN W., SCHREINER M. Effect of temperature increase under low radiation conditions on phytochemicals and ascorbic acid in greenhouse grown broccoli. Agriculture, Ecosystems \& Environment. 119 (1), 103, 2007.

41. MØLMANN J.A., STEINDAL A.L., BENGTSSON G.B., SELJÅSEN R., LEA P., SKARET J., JOHANSEN T.J. Effects of temperature and photoperiod on sensory quality and contents of glucosinolates, flavonols and vitamin $\mathrm{C}$ in broccoli florets. Food Chemistry. 172, 47, 2015.

42. FRANDSEN K.E., SIMMONS T.J., DUPREE P., POULSEN J-C.N., HEMSWORTH G.R., CIANO L., JOHNSTON E.M., TOVBORG M., JOHANSEN K.S., VON FREIESLEBEN P. The molecular basis of polysaccharide cleavage by lytic polysaccharide monooxygenases. Nature Chemical Ciology. 12 (4), 298, 2016.

43. HOPKINS R., GRIFFITHS D., BIRCH A., MCKINLAY R. Influence of increasing herbivore pressure on modification of glucosinolate content of swedes (Brassica napus spp. rapifera). Journal of Chemical Ecology. 24 (12), 2003, 1998. 